\title{
Effect of Obesity on Covid-19 Patients
}

\author{
Celly Devita Febrianti ${ }^{1 *}$, Cicylia Candi $^{2}$, Wahyu Sulistiadi ${ }^{2}$ \\ ${ }^{I}$ Master of Public Health Program, University of Indonesia \\ ${ }^{2}$ Faculty of Public Health, University of Indonesia \\ ${ }^{*}$ Coresponding author. Email : celly.devita@ui.ac.id
}

\begin{abstract}
Background: Covid-19 is a disease that can cause pneumonia, respiratory failure, and death. Patients with severe infections should be admitted to the Intensive Care Unit (ICU) with a ventilator, while the ventilator facilities in the ICU are limited. For this reason, vigilance is needed by knowing conditions that can aggravate Covid-19, one of which is obesity, while existing findings regarding the relationship between obesity and the severity of Covid-19 disease are still inconsistent and adequate. The purpose of this study was to analyze the effect of obesity on the severity of Covid-19. Methods: This study uses a systematic review with the PRISMA method without meta-analysis, by searching for articles from online databases, namely Scopus and ProQuest, using the keywords obesity and covid-19 comorbidities. After selecting the title, the next step is to read the abstract and the article as a whole. Researchers used 12 relevant articles based on research titles and abstracts. Result: Several articles indicated that there was no significant difference in symptoms between patients suffering from obesity and Covid-19 and those suffering only from Covid-19. In subsequent analysis, obese patients have a poor prognosis of ARDS (Acute Respiratory Distress Syndrome), severe symptoms, and a higher mortality rate among Covid-19 patients. Conclusions: Obese patients are at risk for Covid-19 infection. Obesity contributes to the severity and mortality of Covid-19 patients. This condition causes the patient to be admitted to the ICU. In addition, obese patients in adulthood are more susceptible to Covid-19 infection.
\end{abstract}

Keywords: Covid-19, Comorbid, Obesity, Severity, morbidity

\section{INTRODUCTION}

Corona Virus Disease 2019, known as Covid-19, was first discovered in China in December 2019 and has spread rapidly throughout the world. Every day, the number of people infected with Covid-19 continues to increase, this virus has spread to various countries including Indonesia. In Indonesia as of September 11, 2020, as many as 28,351,985 were infected with Covid19, and 8,544 people died [1]. The spread of Covid-19 infection has now become a pandemic which causes health problems and global economic losses [2]. Not only that, Covid-19 has caused the number of people infected to increase so that the death rate is even higher The typical symptoms of Covid-19 can range from mild to severe. Covid-19 is a highly contagious disease and causes respiratory disease in the form of pneumonia which can lead to death [3]. Individuals infected with Covid-19, especially those who have comorbidities such as cardiovascular disease, diabetes, hypertension and obstructive pulmonary disease are more likely to experience serious Covid-19 infection [4].

Wang et al (2020) stated that $(46.4 \%)$ of 138 patients with confirmed Covid-19 had comorbidities, where patients treated in the intensive care unit (ICU) had a higher rate $(72.2 \%)$ than those who were not. admitted to the ICU (37.3\%) [5]. This suggests that comorbidities can be a risk factor that can lead to adverse events and death.

In Indonesia, the available Intensive Care Unit (ICU) facilities are not proportional to the increase in the number of Covid-19 patients, therefore it is necessary to know the characteristics of patients who are at high risk of severity. Research by Denova et al (2020) states that recently the growth rate of hospitalization Hospital stays are dominated by a younger population, namely those aged under 50 who are overweight or obese [6]. A person with a Body Mass Index (BMI) $\geq 30$ is generally considered obese, while someone with a BMI $\geq 25$ is considered overweight or overweight [7]. Research by Kalligeros et al (2020) also found that Covid-19 patients with severe obesity (BMI $\geq 35 \mathrm{~kg} /$ $\mathrm{m} 2$ ) were associated with the risk of entering the Intensive Care Unit (ICU) [8].

Obesity is a risk factor for Covid-19 because obesity can lead to chronic inflammatory conditions and a decrease in the immune system, thereby increasing the individual's susceptibility to Covid-19 infection [9]. Metabolic and inflammatory factors also underlie obese individuals to have a susceptibility to acute respiratory distress syndrome (ARDS). ARDS is the leading cause of death in Covid-19 cases.

There are many reports on the relationship between obesity and the severity of the disease Covid-19, but 
the literature review is still limited. The aim of this study is to obtain more accurate evidence through the effect of obesity on the severity or even the cause of death in Covid-19 cases. The results of this study are expected to provide an overview of risk factors and guidelines for responding and strategies for developing priority procedures for using ventilators to prevent death in Covid-19 cases.

\section{METHOD}

This study uses a systematic review with the PRISMA method without meta-analysis, which is carried out systematically by following the correct research stages or protocol. It can be seen in Figure 1. The articles used werearticles in the ProQuest and Scopus databases published on January 1, 2020 - August 31, 2020. Search using the keywords Covid-19 and obesity. Articles are then checked starting from the title to prevent any discrepancies with the specified topic. After selecting the title, the next step is to read the
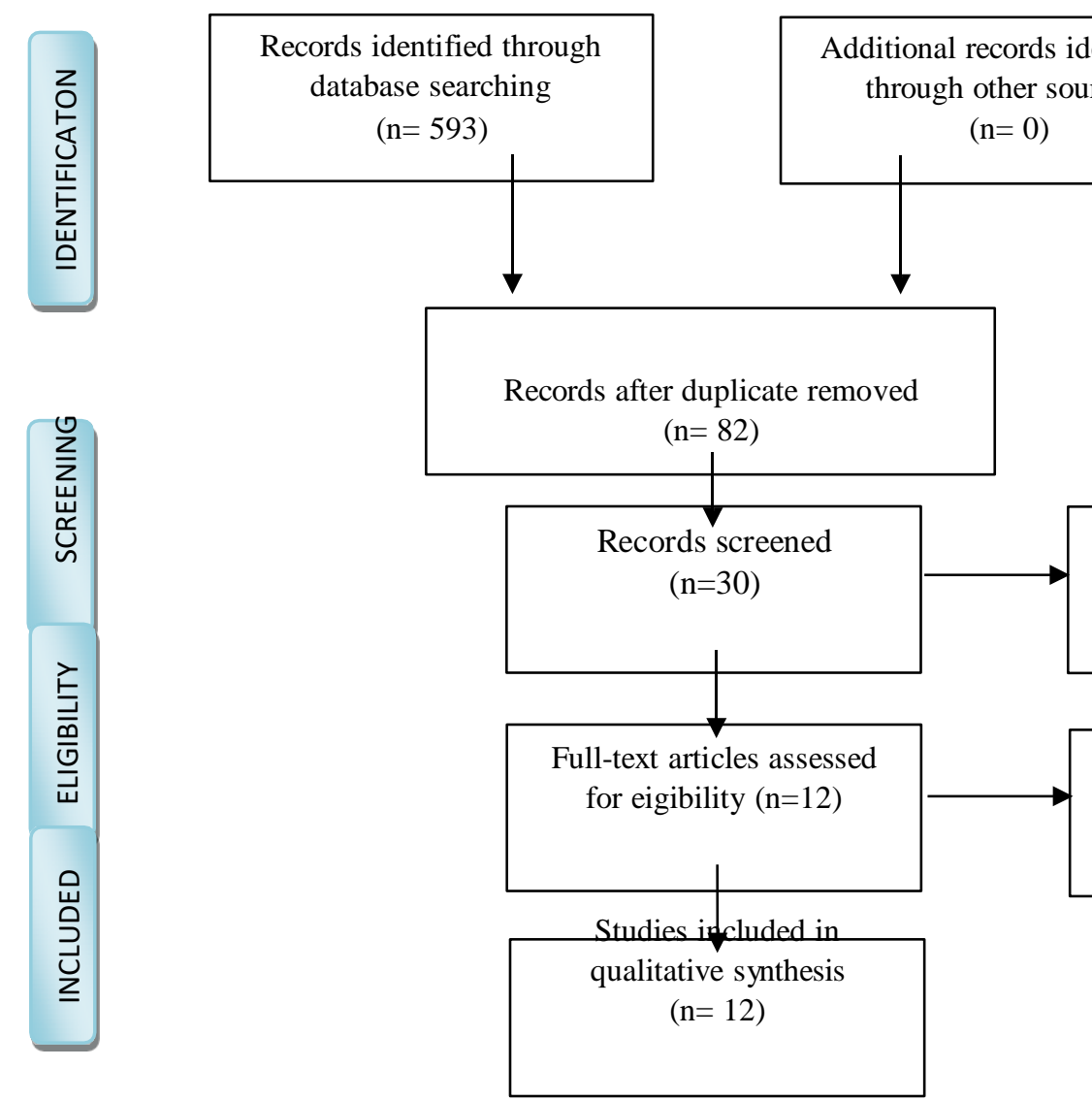

Figure 1. Systematic Review Steps

\section{RESULT} Obesity and Covid-19 and obtained 593 articles (382
The search results for articles used the keywords abstract and the article as a whole. There are inclusion and exclusion criteria in articles which are then synthesized. The inclusion criteria in this study, namely the article must explain the characteristics and prevalence of the disease in Covid-19 patients and the exclusion criteria, namely cases of Covid-19 in animals with SARS (Severe Acute Respiratory Syndrome) and MERS (Middle East Respiratory Syndrome) which are not relevant to Covid-19. .

Data from each article was extracted in standardized form, compiled study citations, baseline characteristics of the included subjects, appropriate interventions, and study findings. Study citations include the name of the first author, year of publication, and title of study. While the characteristics of each study refer to the study design, study location, patient characteristics (age, ethnicity, gender, sample size, BMI and the presence of other comorbidities). We determined extracted comorbidities for hypertension, respiratory system diseases, cardiovascular disease, diabetes mellitus, and dyslipidemia according to the recognized comorbidities for Covid-19.

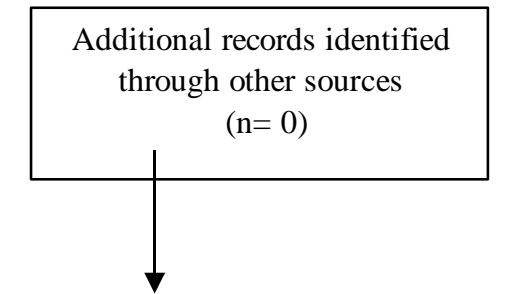

Records excluded

$(n=8)$ with reasons $(\mathrm{n}=10)$
Full-text articles excluded

from ProQuest and 211 from Scopus). The articles were then filtered, for the Proquest online database filtering using the format: Scholarly Journals, Last 12 Months, covid-19 OR obesity, Report OR Case Study, English. As for the online database Scopus uses the 
formats: (covid and obesity) and (limit-to (exactsrctitle, "obesity")) and (limit-to (accesstype (oa))) and (limit-to (pubyear, 2020)) and (limit-to (doctype, "ar")) and (limit-to (exact keyword, “obesity") or limit-to (exactkeyword, "coronavirus disease 2019")) and (limit-to (language, "English") ). Then obtained the relevant articles, namely 82 articles (67 from ProQuest and 15 from Scopus).

Table 1. Results of studies on obesity and covid-19

\begin{tabular}{|c|c|c|c|c|c|c|}
\hline No & Author & Location & Popula & Study Design & Result & \\
\hline 1 & $\begin{array}{l}\text { Bhasin et al, } \\
2020\end{array}$ & $\begin{array}{l}\text { Northy } \\
\text { Memo } \\
\text { Hospit } \\
\text { Chicas }\end{array}$ & $\begin{array}{l}\text { estern } \\
\text { ial } \\
\text { l, } \\
\text { o }\end{array}$ & $\begin{array}{l}227 \text { patients } \\
\text { Covid-19 }\end{array}$ & $\begin{array}{l}\text { a cross-sectional } \\
\text { analysis }\end{array}$ & $\begin{array}{l}\text { Younger patients (age }<50 \text { years) } \\
\text { with COVID-19 had higher mean } \\
\text { BMI than older } \\
\text { patients with COVID-19, with and } \\
\text { without diabetes and hypertension. } \\
\text { This trend did not exist in patients } \\
\text { without COVID-19 hospitalized } \\
\text { during the same time-period. }\end{array}$ \\
\hline 2 & $\begin{array}{l}\text { Denova et al, } \\
2020\end{array}$ & Mexic & \multicolumn{2}{|c|}{$\begin{array}{l}\text { 3,844 patients } \\
\text { who tested } \\
\text { positive for } \\
\text { COVID-19 }\end{array}$} & $\begin{array}{l}\text { Retrospective } \\
\text { case } \\
\text { study }\end{array}$ & $\begin{array}{l}\text { Obesity, diabetes, and hypertension } \\
\text { were significantly associated with } \\
\text { severe COVID-19 on admission and } \\
\text { the association of obesity was } \\
\text { stronger in patients }<50 \mathrm{y}\end{array}$ \\
\hline 3 & $\begin{array}{l}\text { Simonnet et } \\
\text { al, } 2020\end{array}$ & French & \multicolumn{2}{|c|}{$\begin{array}{l}124 \text { consecutive patients } \\
\text { admitted in } \\
\text { intensive care for } \\
\text { SARS-CoV-2 }\end{array}$} & $\begin{array}{l}\text { Retsropective } \\
\text { cohort study }\end{array}$ & $\begin{array}{l}\text { This present study showed a high } \\
\text { frequency of obesity among patients } \\
\text { admitted in intensive care for SARS- } \\
\text { CoV-2. Disease severity increased } \\
\text { with BMI. Obesity is a risk factor for } \\
\text { SARS-CoV-2 severity, requiring } \\
\text { increased attention to preventive } \\
\text { measures in susceptible individuals }\end{array}$ \\
\hline 4 & $\begin{array}{l}\text { Kalligeros et } \\
\text { al, } 2020\end{array}$ & USA & 103 & $\begin{array}{l}\text { patients hospitalized } \\
\text { with Covid-19 }\end{array}$ & $\begin{array}{l}\text { Retsropective } \\
\text { cohort study }\end{array}$ & $\begin{array}{l}\text { Severe obesity (BMI } \geq 35 \mathrm{~kg} / \mathrm{m} 2) \text { was } \\
\text { associated with ICU admission, } \\
\text { whereas history of heart disease and } \\
\text { obesity (BMI } \geq 30 \mathrm{~kg} / \mathrm{m} 2) \text { were } \\
\text { independentlyassociated with the use } \\
\text { of invasive mechanical ventilation } \\
\text { (IMV). Increased vigilance and } \\
\text { aggressive treatment of patients with } \\
\text { obesity and COVID-19 are }\end{array}$ \\
\hline 5 & $\begin{array}{l}\text { Busetto et al } \\
2020\end{array}$ & Italia & & $\begin{array}{l}92 \text { patients covid- } \\
19\end{array}$ & $\begin{array}{l}\text { Quantitative } \\
\text { study }\end{array}$ & $\begin{array}{l}\text { Patients with overweight and obesity } \\
\text { admitted in a medical ward for } \\
\text { SARS-CoV-2 related pneumonia, } \\
\text { despite their younger age, required } \\
\text { more frequently assisted ventilation } \\
\text { and access to intensive or semi- } \\
\text { intensive care units than normal } \\
\text { tients. }\end{array}$ \\
\hline 6 & $\begin{array}{l}\text { Hajifathalian } \\
\text { et al, } 2020\end{array}$ & New Y & ork City & $\begin{array}{l}770 \quad \text { patients } \\
\text { covid-19 }\end{array}$ & $\begin{array}{l}\text { Retrospective } \\
\text { review }\end{array}$ & $\begin{array}{l}\text { Obese patients had an increased risk } \\
\text { of critical illness leading to ICU } \\
\text { admission or death compared to } \\
\text { normal weight individuals. This study } \\
\text { confirms that obesity is a major risk } \\
\text { factor for COVID-19 disease } \\
\text { severity, significantly impacting } \\
\text { disease presentation and critical care } \\
\text { requirements. }\end{array}$ \\
\hline 7 & $\begin{array}{l}\text { Klang et al, } \\
2020\end{array}$ & New Y & ork City & $\begin{array}{l}3.406 \text { patients } \\
\text { covid-19 }\end{array}$ & $\begin{array}{l}\text { Retrospective } \\
\text { analyzed }\end{array}$ & $\begin{array}{l}\text { study demonstrates that hospitalized } \\
\text { patients younger than } 50 \text { with morbid } \\
\text { obesity are more likely to die from } \\
\text { COVID-19. This is particularly } \\
\text { relevant in the western world where } \\
\text { obesity rates are high. }\end{array}$ \\
\hline
\end{tabular}




\begin{tabular}{llll}
\hline 8 & Cai et al, China & $\begin{array}{l}96 \text { patients with } \\
\text { Covid-19 }\end{array}$ & $\begin{array}{l}\text { Retrospective } \\
\text { multicenter } \\
\text { clinical study }\end{array}$
\end{tabular}

BMI was significantly related with clinical manifestations and clinical outcomes of patients with SARSCoV-2 infections. Patients with higher BMIs were more likely to develop ARDS and to experience disease progression. Older age and high BMI are independent risk factors associated with ICU admission in SARS-CoV-2 infected patients, while patients with higher BMIa are more

likely to experience disease exacerbation. For patients with risk factors, clinicians should intervene promptly to avoid disease progression.

\begin{tabular}{|c|c|c|c|c|c|}
\hline 9. & $\begin{array}{l}\text { De Lorenzo } \\
\text { et al, } 2020\end{array}$ & $22 \mathrm{a}$ & $\begin{array}{l}\text { idult patients with } \\
\text { covid-19 }\end{array}$ & $\begin{array}{l}\text { Prospective } \\
\text { observational } \\
\text { study }\end{array}$ & $\begin{array}{l}\text { Obese characteristic with } \\
\text { likely poorly prognosis and an } \\
\text { important misclassification of obesity. } \\
\text { A not negligible number of patients } \\
\text { with normal } \\
\text { BMI could actually have an excess of } \\
\text { adipose tissue and therefore have an } \\
\text { unfavorable outcome such as an obese. } \\
\text { Is } \\
\text { fundamental personalized patients } \\
\text { basing on disease phases. }\end{array}$ \\
\hline 10. & $\begin{array}{l}\text { Steinberg et } \\
\text { al, } 2020\end{array}$ & California & $\begin{array}{l}10 \text { patients with } \\
\text { Covid-19 }\end{array}$ & $\begin{array}{l}\text { nutr } \\
\text { ective } \\
\text { tudy }\end{array}$ & $\begin{array}{l}\text { Obesity appears to be an independent } \\
\text { risk factor for poor outcomes in } \\
\text { young patients with COVID- } 19 \text {. } \\
\text { Future studies examining the clinical } \\
\text { characteristics and risk factors of } \\
\text { COVID-19 patients across large, } \\
\text { diverse populations will strengthen } \\
\text { our understanding of this novel and } \\
\text { complex disease. }\end{array}$ \\
\hline 11 & $\begin{array}{l}\text { Nakeshbandi } \\
\text { et al, } 2020\end{array}$ & New York City & 684 patients & $\begin{array}{l}\text { Retrospective } \\
\text { cohort study }\end{array}$ & $\begin{array}{l}\text { Patients with overweight and obesity } \\
\text { who have COVID-19 are at increased } \\
\text { risk for } \\
\text { mortality and intubation compared to } \\
\text { those with normal BMI. These } \\
\text { findings support the hypothesis that } \\
\text { obesity is a risk factor for COVID-19 } \\
\text { complications and should be a } \\
\text { consideration in management of } \\
\text { COVID-19. }\end{array}$ \\
\hline 12 & $\begin{array}{l}\text { Anderson et } \\
\text { al, } 2020\end{array}$ & New York City & $\begin{array}{l}2466 \text { adults } \\
\text { hospitalized with } \\
\text { laboratorycon } \\
\text { irmed severe } \\
\text { acute respiratory } \\
\text { syndrome } \\
\text { coronavirus } 2 \\
\text { infection over a } \\
45 \text {-day period } \\
\text { with at least } 47 \\
\text { days of in- } \\
\text { hospital }\end{array}$ & $\begin{array}{l}\text { Retrospective } \\
\text { cohort study }\end{array}$ & $\begin{array}{l}\text { Obesity is associated with increased } \\
\text { risk for intubation } \\
\text { or death from COVID-19 in adults } \\
\text { younger than } 65 \text { years, } \\
\text { but not in adults aged } 65 \text { years or } \\
\text { older. }\end{array}$ \\
\hline
\end{tabular}

The articles obtained were then selected which were relevant to the research topic and duplicated. There are
12 relevant articles based on the title and research abstract. Most of the studies used a retrospective cohort 
design to explain the association between individuals with obesity and covid-19. All studies defined obesity using a body mass index (BMI) $\geq 30 \mathrm{~kg} / \mathrm{m} 2$. These criteria are in accordance with those mentioned by WHO regarding the criteria for obesity. The study Bhasin et al, Denova et al, and Klang et al grouped

\section{DISCUSSION}

COVID-19 is a virus that infects the respiratory system, with three classifications of signs and symptoms, namely mild, severe, and critical [10] Signs and symptoms begin with the same mild symptoms such as flu, fever, fatigue, and dry cough. [6], while the signs and symptoms of severe infection such as shortness of breath, diarrhea, pneumonia, and high fever $\left(>39^{\circ} \mathrm{C}\right)$ [11]). Patients who show severe symptoms such as experiencing respiratory failure, septic shock, and multi-organ failure, are at risk of causing death [12]. Simonnet et al's study found that $(47.5 \%)$ of 124 Covid-19 patients hospitalized were categorized as obese (BMI $\geq 30)$ [13]. Busetto et al's study also found that obesity cases were found in two-thirds of the Covid-19 patient population studied [14]. Denova et al's study also found that patients with COVID-19, among them $(17.4 \%)$ were obese, $(14.5 \%)$ had diabetes, $(18.9 \%)$ had hypertension, and $(2.8 \%)$ had the disease. cardiovascular disease [6] This shows that individuals who are obese or who have a body mass index $(\mathrm{BMI}) \geq 30$ are susceptible to infection with Covid-19.

Obesity can lead to chronic inflammatory conditions and is associated with impaired immune response and thus increases the individual's susceptibility to Covid19 infection[9][6]. The immune system, which plays an important role in the pathogenesis of COVID 19, is also an important element in adipose tissue inflammation due to obesity. This inflammation of the adipose tissue has been associated with metabolic dysfunction, which in turn is associated with dyslipidemia, type 2 diabetes, hypertension, and cardiovascular disease [8]. Excess adipose tissue in the upper respiratory tract in obese patients can also result in airway obstruction and the risk of hypoxia [15].

The study Bhasin et al, Denova et al, and Klang et al grouped study subjects by age less than 50 years and over 50 years. Obese Covid-19 patients who are less than 50 years of age have worse Covid-19 symptoms. Obese patients have a risky respiratory physiology, which involves decreased functional residual capacity and expiratory reserve volume, as well as hypoxemia and abnormalities of ventilation / perfusion [15]. Patients tend to have a prognosis of ARDS (Acute Respiratory Distress Syndrome) so they need a ventilator [16] [6] [17]. Covid-19 patients of normal weight are less likely to have bad breathing problems and do not need a ventilator. study subjects by age under 50 years and over 50 years. Research by Klang et al, Bhasin et al, Denova et al, stated that obese Covid-19 patients aged under 50 years are at risk of having a worse severity than Covi-19 patients with normal BMI.

Nakeshbandi et al, Hajifathalian et al, and Kalligeros et al revealed that a high BMI in Covid-19 patients is directly proportional to the risk of mortality and intubation. Obesity cannot be considered a trivial problem, given the high prevalence of obesity in Indonesia[15][18][8]. Indonesia is in the top 10 countries with the highest obesity population. And during the Covid-19 pandemic, such as at this time, several studies stated that obese individuals have problems with the immune system so they are at risk of being infected with Covid-19. And individuals with obesity who have been infected with Covid-19 have up to five times the risk of having bad symptoms such as ARDS (Acute Respiratory Distress Syndrome) to death. COVID-19 is very contagious, it is important to implement prevention of Covid-19 transmission such as self-isolation or quarantine, using personal protective equipment such as masks, washing hands with soap or disinfectant, and maintaining distance from other people. You also need to eat high-nutritional foods or multivitamins, and get some exercise. For individuals who are overweight, let's cultivate the Healthy Living Society Movement (GERMAS) by regulating eating patterns, physical activity, and carrying out regular health checks. There is also a need for preparedness from health facilities if there are confirmed patients with Covid-19 who are overweight, because they have a risk of worsening symptoms so they need breathing aids and ICU rooms.

\section{CONCLUSION}

The results showed that obese individuals in adulthood are more susceptible to Covid-19 infection. To prevent the increasing number of individuals with obesity, it is necessary to make preventive efforts, one of which is by supporting the Healthy Living Community Movement (GERMAS). Obesity is also a risk factor that contributes to the severity of Covid-19 patients. Obese Covid-19 patients have a poor prognosis of ARDS (Acute Respiratory Distress Syndrome), severe symptoms, and a higher mortality rate among Covid19 patients. There needs to be guidelines for health facilities in responding and strategies to develop priority procedures for using ventilators to prevent deaths in Covid-19 cases.

\section{REFERENCES}

[1] "Peta Sebaran | Gugus Tugas Percepatan Penanganan COVID-19." https://covid19.go.id/peta-sebaran (accessed Sep. 17, 2020).

[2] C. Basile et al., "Recommendations for the prevention, mitigation and containment of the 
emerging SARS-CoV-2 (COVID-19)

pandemic in haemodialysis centres," Nephrol. Dial. Transplant., vol. 35, no. 5, pp. 737-741, May 2020, doi: 10.1093/ndt/gfaa069.

[3] L. Panahi, M. Amiri, and S. Pouy, "Risks of Novel Coronavirus Disease (COVID-19) in Pregnancy; a Narrative Review.," Arch. Acad. Emerg. Med., vol. 8, no. 1, p. e34, Mar. 2020, doi: $10.22037 /$ aaem.v8i1.595.

[4] W. Guan et al., "Clinical Characteristics of Coronavirus Disease 2019 in China," N. Engl. J. Med., vol. 382, no. 18, pp. 1708-1720, Apr. 2020, doi: 10.1056/NEJMoa2002032.

[5] D. Wang et al., "Clinical Characteristics of 138 Hospitalized Patients with 2019 Novel Coronavirus-Infected Pneumonia in Wuhan, China," JAMA - J. Am. Med. Assoc., vol. 323, no. 11, pp. 1061-1069, Mar. 2020, doi: 10.1001/jama.2020.1585.

[6] E. Denova-Gutiérrez et al., "The association between obesity, type 2 diabetes, and hypertension with severe COVID-19 on

admissi.9802moby.224yxicans," Obesity, 2020,

[7] WHO, "Obesity and overweight: Fact sheet," WHO Media Cent., no. June, pp. 1-6, 2016, [Online]. Available: http://www.who.int/mediacentre/factsheets/fs 311/en/.

[8] M. Kalligeros et al., "Association of Obesity with Disease Severity Among Patients with Coronavirus Disease 2019," Obesity, vol. 28, no. 7, pp. 1200-1204, Jul. 2020, doi: $10.1002 /$ oby.22859.

[9] F. P. De Heredia, S. Gómez-Martínez, and A. Marcos, "Chronic and degenerative diseases: Obesity, inflammation and the immune system," in Proceedings of the Nutrition Society, 2012, vol. 71, no. 2, pp. 332-338, doi: $10.1017 /$ S0029665112000092.

[10] A. Bhasin, H. Nam, C. Yeh, J. Lee, D. Liebovitz, and C. Achenbach, "Is BMI Higher in Younger Patients with COVID-19? Association Between BMI and COVID-19 Hospitalization by Age," Obesity, p. oby.22947, Aug. 2020, doi: 10.1002/oby.22947.

[11] S. H. Cai, W. Liao, S. W. Chen, L. L. Liu, S. Y. Liu, and Z. D. Zheng, "Association between obesity and clinical prognosis in patients infected with SARS-CoV-2," Infect. Dis. Poverty, vol. 9, no. 1, p. 80, Jun. 2020, doi: 10.1186/s40249-020-00703-5.

[12] M. R. Anderson et al., "Body Mass Index and Risk for Intubation or Death in SARS-CoV-2 Infection," Ann. Intern. Med., Jul. 2020, doi:
$10.7326 / \mathrm{m} 20-3214$

[13] A. Simonnet et al., "High Prevalence of Obesity in Severe Acute Respiratory Syndrome Coronavirus-2 (SARS-CoV-2) Requiring Invasive Mechanical Ventilation," Obesity, vol. 28, no. 7, pp. 1195-1199, Jul. 2020, doi: 10.1002/oby.22831.

[14] L. Busetto et al., "Ubesity and CUVID-19: An Italian Snapshot," Obesity, vol. 28, no. 9, pp. 1600-1605, Sep. 2020, doi: 10.1002/oby.22918.

[15] M. Nakeshband et al., "'Ine impact of obesity on COVID-19 complications: a retrospective cohort study," Int. J. Obes., vol. 44, no. 9, pp. 1832-1837, Sep. 2020, doi: 10.1038/s41366-020-0648-x.

[16] A. Bhasin, H. Nam, C. Yeh, J. Lee, D. Liebovitz, and C. Achenbach, "Is BMI higher in younger patients with COVID-19? Association between BMI and COVID-19 hospitalization by age," Obesity, pp. 0-1, 2020, doi: 10.1002/oby.22947.

[17] E. Klang, G. Kassim, S. Soffer, R. Freeman, M. A. Levin, and D. L. Reich, "Severe Obesity as an Independent Risk Factor for COVID-19 Mortality in Hospitalized Patients Younger than 50," Obesity, vol. 28, no. 9, pp. 1595-1599, Sep. 2020, doi: $10.1002 /$ oby.22913.

[18] K. Hajifathalian et al., "Obesity is Associated with Worse Outcomes in COVID-19: Analysis of Early Data from New York City,” Obesity, vol. 28, no. 9, pp. 1606-1612, Sep. 2020, doi: 10.1002/oby.22923. 